Journal of Advanced College of Engineering and Management, Vol. 3, 2017

\title{
EXPLORING CRITICAL THINKING FOR SECONDARY LEVEL STUDENTS IN CHEMISTRY: FROM INSIGHT TO PRACTICE
}

\author{
Kamal Prasad Acharya \\ Lecturer, Department of Science Education, Central Department of Education, T.U, Kirtipur \\ Email Address: kamalacharya@tucded.edu.np
}

\begin{abstract}
This article examines hands-on activities based on improvisation of low cost and no cost materials that have direct and indirect impacts on critical thinking practices in secondary science classrooms in Nepal. It also tries to explore the science teachers' activities for the development of critical thinking practices in chemistry for the secondary school students. Meanwhile, the collaborative and the socio-cultural theoretical dimensions have been taken as the conceptual bases for this study. This study has highlighted the major conceptual and methodological issues in identifying, assessing and exploring critical thinking as well as the implication of chemistry education for the exploration of children's creative and critical thinking. Based on the qualitative research approach, this study used classroom observation and an interview with the students as the tools to pursue the research objectives. There is a great role of hands-on activities to foster the critical thinking in chemistry in an informal class setting.
\end{abstract}

Keywords: Hands-on activities, Critical thinking, Meta-cognition, Chemical Concept

\section{Introduction}

The ability to think critically is an essential life skill in Nepalese society today; as the world changes at an ever-faster pace and economies become global, young adults are entering an expanding, diverse job market. It is necessary now more than ever before to ensure that secondary level students possess the thinking power too flexibly and creatively adapt to new venue in the world market. According to Acharya (2016), the majority of Nepalese schools fail to teach critical thinking and, as a result, the majority of our students do not practice it (p. 3). Hayes and Devitt (2008) stated, critical thinking strategies are not extensively developed or practiced during primary and secondary education (p. 65). School systems need to amend curriculum to ensure that high school graduates have developed a solid foundation of critical thinking skills, enabling them to be more successful in their pursuits after secondary school.

In the Nepalese school system, pressure has been laid to demonstrate student progress and competency i.e., standardized test scores. Rather than embarking on frustrating attempts to cram students full of simple recall facts in the weeks prior to a round of standardized tests, it may be more beneficial long-term for students to be able to utilize factual information as a framework for critical exploration of broader concepts. Teachers are obligated to help students develop the skills necessary to synthesize the nuances of a modern, glocal society.

High school science teachers take obedient, compliant, dependent, and submissive students as good students and those who are independent and express personal opinions different from teachers are regarded as showing disrespect. Learning in a pin-drop silent classroom is considered to be the best in the high schools of Nepal. Classroom discussions are rarely encouraged by the science teachers. Students are expected to be passive receivers of the content knowledge poured by a teacher. In a classroom, the science teacher is usually found to be solving the problems and the students are copying the problem (Acharya, 2016). Learning science needs an amicable blend of cognitive, affective and psychomotor activities through hands-on, minds-on and hearts-on activities that help 
develop critical thinking habits in students (Gardner, 2008 p. 1). A teacher-centered approach doesn't support adequately for classroom talk, discussion and thinking. Students sit in the neat, orderly and well-arranged rows in the classroom. The practice of a dogmatic approach to teaching science makes students feel monotonous and thus they are bound to memorize the procedures.

Critical thinking is an ability to think outside the box or to look at the situation from another point of view and to think beyond the limits that will result of very useful creative solutions. Critical thinking can also be understood from characteristics of critical thinkers. Reigeluth (2002) states that the dispositions of open-mindedness and curiosity as the component of creative thinking, seeking truth and understanding. Being strategic and being skeptical as components of critical thinking and reflective thinking as meta-cognition. This indicates that critical thinking needs strategic plans and actions. Individuals using critical thinking are perceived as self-directed, self-disciplined, selfmonitoring using self-corrective because their thinking is directed towards standards of excellence and entails a commitment to overcoming human native egocentrism and sociocentrism (Young, $\mathrm{H}$. 2003). But in our context, students are not supposed to talk before being asked or permitted to do so especially in the case of critical comments.

Paulo Freire in his book 'Pedagogy of the Oppressed' (1970), has pointed out the limitations of the education system. The existing education system. Banking system cannot make people creative and conscious about their oppression. Facts. concepts, skills and principles are direct objects whereas problem solving, learning how to learn, intellectual development, working individually, working in group and positive attitudes are indirect objects of science learning. Science classroom discourse goes around these objects. Science (direct or indirect) is a form of reasoning. Reasoning is developed in different ways. Thinking scientifically consists of thinking in a logical manner, formulating and testing conjectures, making sense of things, and forming and justifying judgments, inferences, and conclusions.

\section{Objectives of the Study}

The study is based on the following objectives:

- to examine strategies for developing critical thinking skills in high school students in chemistry.

- to develop approaches to learning chemical concepts by fostering critical thinking practices.

- $\quad$ to explore the reflective pedagogy on critical thinking practices at the secondary level schools of Nepal.

\section{Methodology}

This study uses the qualitative research design. Interpretivism research methodology is especially focused. This study highlights the conceptual and methodological issues in identifying and assessing secondary level students" critical thinking practices in chemistry. As a qualitative research design, this study demands data from two sources namely participant classroom observations and in-depth interview with thestudents of the secondary level.

These sources helped the researcher to investigate the basic epistemology, ontology and axiology of critical thinking, while the data were collected through multiple methods and yielded the same results. This type of combination of data collection compensated the weaknesses of another approach to data generation. 


\section{Literature Review}

\section{Philosophical approach of Critical Thinking}

The writings of Socrates, Plato, Aristotle, and more recently, Matthew Lipman and Richard Paul, exemplify the philosophical approach. This approach focuses on the hypothetical critical thinker, enumerating the qualities and characteristics of the person rather than the behaviors or actions the critical thinker can perform (Lewis \& Smith, 1993; Thayer-Bacon, 2000). Sternberg (1986) has noted that this school of thought approaches the critical thinker as an ideal type, focusing on what people are capable of doing under the best of circumstances. Accordingly, Richard Paul (1992) discusses critical thinking in the context of perfections of thought (p. 9).

Those working within the philosophical tradition also emphasize qualities or standards of thought. For example, Bailin (2002) defines critical thinking as thinking of a particular quality essentially good thinking that meets specified criteria or standards of adequacy and accuracy. Further, the philosophical approach has traditionally focused on the application of formal rules of logic (Lewis \& Smith, 1993; Sternberg, 1986). One limitation of this approach to defining critical thinking is that it does not always correspond to reality (Sternberg, 1986). By emphasizing the ideal critical thinker and what people have the capacity to do, this approach may have less to contribute to discussions about how people actually think.

Definitions of critical thinking emerging from the philosophical tradition include:

"The propensity and skill to engage in an activity with reflective skepticism" (McPeck, 1981, p. 8); "reflective and reasonable thinking that is focused on deciding what to believe or do" (Ennis, 1985, p. 45); "skillful, responsible thinking that facilitates good judgment because it 1) relies upon criteria, 2) is self-correcting, and 3) is sensitive to context" (Lipman, 1988, p. 39); "purposeful, self-regulatory judgment which results in interpretation, analysis, evaluation, and inference, as well as explanation of the evidential, conceptual, methodological, criteriological, or conceptual considerations upon which that judgment is based" (Facione, 1990, p. 3).

It's clear that teachers, especially at the secondary level, need to embed a critical thinking approach within their domains and curricula. Bruning et.al. (2004) pointed out that the most effective educators teach critical thinking skills in a sequential, orderly fashion (p. 187). Bruning (2011) went on to state that routine critical thinking practice benefits all students; in fact, research supports the fact the explicit instruction and extended practice are more influential than mere aptitude (p. 177). In the same way, McCollister and Sayler (2010) encouraged appropriately challenging problem solving opportunities to give students the change to apply critical thinking within any content area (p. 42). The adage that practice makes perfect is applicable to disciplined critical thinking, as research shows that less skilled students can reach higher levels of achievement than more intelligent peers based on continual, guided critical thinking practice (Bruning et.al, 2004, p. 177). Implementation of any critical thinking program at the high school level must be designed with an end-goal of students developing the ability to assess, analyze, and evaluate a problem independently and with confidence in the accuracy of their thinking.

In the secondary level chemistry classroom, research supports the need to explicitly teach critical thinking and reading strategies; a generation of research supports this approach as the best means to help students develop higher order thinking and comprehension skills (Bruning et.al., 2004, p. 288).Mendelman (2007) stated that a strong critical thinking program should be designed to gradually progress from the basic to the complex (p. 300). Teachers need to scaffold specific thinking strategy instruction, beginning with basic questioning strategies, then build to develop the ability to inference, as well as analyzing, synthesizing, and evaluating skills. To ensure development of critical thinking 
strategies, implementation of instructional activities that provide an opportunity for discussion related to topics, concepts and intellectual skills are necessary (Hayes \&Devitt, 2008, p. 66). As educators, how gratifying to contemplate the idea that critical thinking instruction will not only make our students employable, but may also prompt them to become better citizens of the world.

\section{Result and Discussion}

Secondary level students in Nepal need to be a place that involves them in chemical concepts in rich, authentic, collaborative work; that takes responsibility for building 21 st century skills; and that uses a diverse program of assessment to document students' growth in such skills (Coughlin, 2010, p. 52). Schools are faced with the challenge of redesign in an effort to create an environment where students build skills that ensure success in the chemical concept in a competitive world. Without redesign the chemistry curriculum and the classroom dynamics, secondary level schools run the risk of becoming irrelevant. Basic factual knowledge in chemistry is readily available through the internet, and this information is packaged for technology based systems that not only mimic traditional classroom delivery, but at times, surpass traditional classroom formats (ibid.). The skills include broad concepts such as creativity, innovation, problem solving, communication, collaboration, teamwork, and critical thinking, as well as media and technology literacy (Senechal, 2010, p. 5). The ability to analyze and creatively adapt to new situations is at the heart of critical thinking.

According to Paul and Elder (2008), critical thinking provides a vehicle for educating the mind (p. 88). Secondary level chemistry classroom provides a unique environment conducive to learning and practicing critical thinking strategies. In fact, to be productive members of society, students need to demonstrate the ability to think critically when they read and as they understand both in written format and to do hands on activities.

\section{Bitter Reality: Situation of the Secondary Level Students}

The problem, and sad reality, is that many secondary students, and secondary educators, are adapting curricula to help high school students develop and exercise critical thinking skills. Too many secondary schools are awarding the degree without equipping students to handle the rigorous thinking to develop the chemical concept of chemistry. Teaching students to merely memorize facts easily found on the internet, we should instead teach them how to think: clearly, accurately, precisely, relevantly, deeply, broadly, logically, significantly, fairly for the better understanding of chemical concepts.

It is found that many students perceived chemical conceptsby cramming the night before a test, instead of inquisitively examining a concept and attempting to synthesize it into their own lives. In a class that consists mainly of lectures with periodic quizzes and examinations, students can often get a passing grade by cramming the night beforetests (Paul \& Elder, 2008, p. 35). The results of these assessments may be misleading; a student who crams for an exam may be able to pass a test, implying that the student is demonstrating proficient content mastery of the chemical concept. However, the problem is that most cramming feeds only the short-term memory; there's little assurance that students have put forth the effort, and utilized habits of critical thinking. Mere memorization does not equate to thoughtful and insightful learning for the life time.

The tendency of students to equate learning with short-term proficiency of fact recall of symbols and units that make superficial and impressionistic learning that does not help students for the clear picture of the concepts. Rather it makes the real concepts vague, often erroneously, creating misleading facsimiles of what they read. They cannot be trusted to accurately capture the meaning of the texts they read (Paul \& Elder, 2009). Many students fail to recognize that they are not learning the skills that equate to handle practical activities in chemistry. Yet, it is the knowledge of these skill 
components and proficiency in applying them that lead to skillful thinking (Beyer, 2008, p. 197). Secondary level chemistry courses are designed to the students to pass without ever being required to think deeply, and too many high school instructors design courses in which they work harder than their students (Paul \& Elder, 2008, p. 35). The traditional textbook approach read a chapter and test is no longer conducive to a rapidly evolving global context. Focus on traditional texts is inadequate as they do not allow for a full consideration of how texts and their readers are shaped by socially and culturally constructed practices related to beliefs, attitudes, and norms.

Traditional educational structures need to adapt or risk becoming irrelevant to 21 st century learners; schools also need to help students expand their attention spans. Digital media and technology are now diminishing the influence of the traditional gatekeepers by pushing information out to the public, enabling self-directed learners to become more and more independent (Coughlin, 2010, p. 48). Because our students live in a digital age, educators need to meet students where they're at and use mediums students are already familiar with to develop and practice critical thinking skills.

\section{Students' Critical Thinking Perceptions}

In the query of which teaching method do teachers use, almost all the students said that lecture method is being used to teach and there is no extra periods to do laboratory activities of teaching. This method of teaching maintains pin drop silent classes. They further replied that we need to understand facts, figures and data in the context of teaching chemistry and of a conceptual knowledge is gained by discussion. Students argue that there need to be more interactions between students and teachers but they are not applying it in the class. Students are the victims of narration sickness. It hinders the critical thinking practices among the students.

Table 1 Understanding on Critical Thinking

\begin{tabular}{|c|l|c|}
\hline S.No. & Understanding of Critical Thinking & Argument \\
\hline 1. & Thinking what we studied (chemical concepts) & NS \\
\hline 2. & Proving logic on every cases (practical as well as theory) & S \\
\hline 3. & Critical thinking means analyzing a situation or a case & NS \\
\hline 4. & Multiple thinking at the time of capturing chemical concepts & S \\
\hline 5. & Providing reason of abstract ideas of chemistry & S \\
\hline 6. & Creative and critical thinking are same & NS \\
\hline
\end{tabular}

Note: S: supportive NS: Non supportive

The arguments given show that secondary science levelstudents believe on dogmatic approach of teaching and learning practices and they are not adopting to explore the knowledge of chemical concepts.To develop critical thinking in chemistry classrooms, it is argued that students enjoy variety, and for effective learning, a range of teaching methods is needed, including group discussion and field visit outside the classroom. In this context, teachers said that critical thinking is very necessary to impart chemical knowledge and its use in daily life but the question is how we develop criticality of students in science classrooms. Teachers argued that the use of collaborative and cooperative learning is best for this practice but at the same time they said that we are overloaded with classes. So it is difficult us to promote critical thinking among students despite its importance. 


\section{Science Process Skills and Critical Thinking Practices}

Secondary level science students argue that the skills of handling apparatus, observation, recording the data manipulation, etc. are very important to learn science. The collaborative and interactive set of actions between teachers and learners are helpful to develop reasoning, hypothesizing and analyzing the matter and the event. To develop critical thinking practices of students, multidimensional approaches can address the learners to value their self. Democratic environment and laboratory work is necessary to develop critical mindset among secondary level students.

Table 2 Science Process Skills and Critical Thinking of Chemical Concepts

\begin{tabular}{|c|l|c|}
\hline S. No. & Type of science process skills & Argument \\
\hline 1. & $\begin{array}{l}\text { Observation (Good observations are essential in learning to develop science } \\
\text { process skills) }\end{array}$ & $\mathrm{S}$ \\
\hline 2. & $\begin{array}{l}\text { Classification (After making observation, it is important to notice } \\
\text { similarities, differences, comprehend the number of objects, events, and } \\
\text { chemical concepts) }\end{array}$ & $\mathrm{NS}$ \\
\hline 3. & $\begin{array}{l}\text { Measurement (Measurement is important in collection, comparison and } \\
\text { interpreting of data) }\end{array}$ & $\mathrm{S}$ \\
\hline 4. & \begin{tabular}{l} 
Communication (It is important to share our experiences) \\
\hline 5.
\end{tabular} & $\begin{array}{l}\text { Inferring (It acts as a link between what is observed and what is already } \\
\text { known) }\end{array}$ \\
\hline 6. & Prediction (It is an educated guess based on observations and inferences) & $\mathrm{S}$ \\
\hline
\end{tabular}

Note: S: Supportive NS: Non supportive

Students argue that the classroom activities should be dynamic, interactive and democratic where the pupils should get the opportunity to express their feeling and ideas in a friendly environment. In my findings, in such environment students can generate new knowledge. To provide such environment within the classrooms, science teachers should be democratic and apply the diversified and multidimensional teaching learning strategies in the classrooms. It helps to develop science process skills that ultimately develop critical thinking habit on secondary students.

From the above saying I found that classroom activities can be carried out by interacting, discussing and participating in group work in a collaborative method under the guidance of the teacher. Regarding this view, the learners should get opportunities to explore knowledge from the constructive way of knowledge generation. Constructivists' view of learning is an active process where learners should learn to discover principles, concepts and facts for themselves; hence there is the importance of encouraging guesswork and intuitive thinking in learners (Anderson, 2001). Similarly, Vygotsky said that the significant implications for peer collaboration is that of the zone of proximal development (ZPD), defined as the distance between the actual developmental level as determined by independent problem-solving and the level of potential development as determined through problem solving under guidance or in collaboration with more capable peers. 


\section{Summative Evaluation and Critical Thinking}

Students' motivation on one-shot summative examination is the major factor that kills criticality among the secondary science students. The focus on exams in educational practices further reinforces performance orientation and motivation to achieve in examinations among our students. Academic motivation revealed that in societies where individuals are socialized to conform to group norms and duties, to emphasize social relationship and to work hard to promote the eminence of the group, its members tend to show high motivation to socially demonstrate successful performance (Depover, C. \& Quintin, J. 1992). Culture of Nepalese students is linked to the use of rote learning and memorization, and has been associated with poor learning outcomes; whereas the deep learning approach is related to the strategies of understanding meaning and has been associated with good learning outcomes. It is possible by critical thinking practices in science classrooms. Students learning approaches are reinforced by students' patterns of communication styles and behaviors. Students are often perceived as passive, compliant, uncritical, rarely asking questions or volunteering answers, and unwilling to make public critiques.

Table 3 Summative Evaluation and Critical Thinking

\begin{tabular}{|c|l|c|}
\hline S. No. & Evaluation Techniques Description & Argumentation \\
\hline 1. & $\begin{array}{l}\text { Summative evaluations help students to understand the chemical } \\
\text { concepts. }\end{array}$ & $\mathrm{S}$ \\
\hline 2. & $\begin{array}{l}\text { Summative evaluation is not good to develop critical thinking } \\
\text { among science students. }\end{array}$ & $\mathrm{NS}$ \\
\hline 3. & \begin{tabular}{l} 
One shot final examination hinders critical thinking practices. \\
\hline 4.
\end{tabular} & $\begin{array}{l}\text { Formative evaluation system develops criticality in chemical } \\
\text { concepts. }\end{array}$ \\
\hline 5. & $\begin{array}{l}\text { Summative evaluation is based on bookish knowledge. } \\
\text { E. }\end{array}$ & $\begin{array}{l}\text { Evaluation demands pin drop silent teaching learning activities } \\
\text { and support the banking concept of education. }\end{array}$ \\
\hline
\end{tabular}

Note. S: Supportive NS: Non supportive

I found that method of teaching depends on the teachers' baggage and how he/she is grown up and what was his/her socio-cultural backups. How people judge differently the similar task with different baggage is relative. This depends upon the disposition of the person. Bell (2000) conception of critical thinking also reflects the significance of dispositions. In the interview with the teachers, they have given different perceptions about critical thinking practices in the science classrooms and students learning activities. 


\section{References}

1. Acharya, K. P. "Critical Thinking in Teaching Science at Secondary Level: Perceptions and Practices". A mini-research report published from the Research Division, Tribhuvan University, Kirtipur, (1016).

2. Anderson, M., "Individual Characteristics and Web-Based Courses", (2001). Online Accessed from http://www.k12schoolnetworking.org/2008/presentations/mandl.pdf, 8 July 2008 .

3. Bailin, S., "Critical thinking and science education. Science \& Education”, 11(4), 361-375, (2002).

4. Bell, P., "Scientific Arguments as Learning Artifacts: Designing For Learning from the Web with Kie", (2000). Online Accessed from http//svwv.designbasedresearch.orgh•eppubs/bell1inn.pdf, 10 August 2008.

5. Beyer, B., "How to teach thinking skills in social studies and history. Social Studies", 99(5), 196- 201(2008).. Retrieved from http://www.socialstudies.org/

6. Bruning, R. H., Schraw, G. J., Norby, M. M., \&Ronning, R. R. “Cognitive psychology and instruction (4th ed.)”. Upper Saddle River, New Jersey: Pearson Prentice Hall, (2004).

7. Bruning, R. H., Schraw, G. J., Norby, M. M., \&Ronning, R. R. "Cognitive psychology and instruction (4th ed."). Upper Saddle River, New Jersey: Pearson Prentice Hall, (2004).

8. Coughlin, E. "High schools at a crossroads. Educational Leadership", 67(7), 48. (2010). Retrieved from http://www.ascd.org/publications/educational-leadership.aspx

9. Depover, C. \& Quintin, J. "Learner Control Versus Computer Control In A Professional Training Context." In M Giardina (Ed.). Interactive Multimedia Learning Environments (Pp.234-247) (1992). Berlin: Springer.

10. Facione, P. A. "The disposition toward critical thinking: Its character, measurement, and relation to critical thinking skill”. Informal Logic, 20(1), 61-84, (2000).

11. Gartner, H. "Learning Environment Design Guidelines." Paper Presented At The Meeting Of The Association For Educational Communications And Technology. New Orleans, (1993). http://www.kl2schoolnetworkin -, ,or,-,/2008/presentations/mandl.Pdf

12. Hayes, K., \&Devitt, A. "Classroom discussions with student-led feedback: a useful activity to enhance development of critical thinking skills". Journal of Food Science Education, 7(4), 6568(2008). Retrieved from http://www.ift.org/knowledge-center/read-ift-publications/journalof-foodscience-education.aspx

13. Hayes, K., \&Devitt, A." Classroom discussions with student-led feedback: a useful activity to enhance development of critical thinking skills. " Journal of Food Science Education, 7(4), 6568. (2008). Retrieved from http://www.ift.org/knowledge-center/read-ift-publications/journalof-foodscience- education.aspx

14. Heyman, G. D. "Children's critical thinking when learning from others". Current Directions in Psychological Science, 17(5), 344-347 (2008)..

15. Lewis, A., \& Smith, D. “Defining higher order thinking”. Theory into Practice, 32(3), 131137(1993). 
16. McCollister, K. \&Sayler, M. "Lift the ceiling: increase rigor with critical thinking skills". Gifted Child Today, 33(1), 41-47(2010). Retrieved from http://journals.prufrock.com/IJP/b/gifted-childtoday

17. McPeck, J. E. “Critical thinking and subject specificity”: A reply to Ennis. Educational Researcher, 19(4), 10-12 (1990).

18. Mendelman, L. "Critical thinking and reading”. Journal of Adolescent and Adult Literacy, 51(4), 300-304 (2007). Retrieved from http://www.reading.org/General/Publications/Journals/jaal.aspx

19. Paul, R., \& Elder, L. “Critical thinking: strategies for improving student learning”, part II. Journal of Developmental Education, 32(2), 34-35(2008). Retrieved from http://www.ncde.appstate.edu/publications/jde/

20. Senechal, D. "The most daring education reform act of all". American Educator, 34(1), 416(2010). Retrieved from http://www.aft.org/newspubs/periodicals/ae/issues.cfm 